\title{
PRISON EDUCATION CHARACTERISTICS AND CLASSROOM MANAGEMENT BY PRISON TEACHERS
}

\author{
Ergin Gashi \\ Ph.D. Candidate, Faculty of Languages, Cultures, and Communication, \\ South East European University,Tetovo, North Macedonia, \\ ergin.gashi@live.com
}

\begin{abstract}
The purpose of this research will be to present the classroom management issues faced by prison teachers and introduce strategies applied by prison teachers managing them within the formal education system in correctional service. Cell classrooms, inmate students, and prison teachers' characteristics and the importance of prison education are to be analyzed within Kosovo Correctional Service. To reach these goals three questions will be raised: 1 . What are the classroom management issues in prison schools? 2. Are the prison teachers professionally prepared to teach to inmate students? and 3. Do prison schools differ from schools in the common world?

This study will be introduced through qualitative data and a literature review as instruments of the study dedicated to prison classroom management and characteristics, teachers and inmates' responsibilities and benefits within the informal education system within Kosovo Correctional Service. The research findings revealed that similar classroom management issues are present in prison schooling compared to classrooms in the free world; prison teachers are not additionally prepared to teach in prison classrooms to inmate students. Prisoners, who plan to rehabilitate and reintegrate themselves through formal prison education, want their circumstances and prison characteristics to be taken into consideration by all factors involved in their schooling within prison walls.
\end{abstract}


Keywords: Classroom management, prisoner, student, prison, teacher, Kosovo Correctional Service

\section{INTRODUCTION}

No matter their background or origin, all people deserve a decent education during their lifetime. Article 26 of the UN Declaration on Human Rights (1948) states in paragraphs "(1) Everyone has the right to education. Education shall be free, at least in the elementary and fundamental stages... (2) Education shall be directed to the full development of the human personality." This concept also embraces our citizens who are serving time within prison facilities for the crimes committed.

Too many difficulties appear in the way of a productive, manageable, and engaging class planned to be offered, within prison education, by a prison teacher. Classroom management plays an important role in creating an efficient and interesting learning setting for inmate students who come from different ethnic, religious, or social backgrounds.

Because of its importance, classroom management can be identified as a nightmare for most teachers of all levels and settings. The beginner teachers face it more in comparison to the experienced teachers, while the future teachers reflect their anxiety by creating the worse possible scenarios created about classroom management issues. It is considered as the main reason that forces teachers to think twice before applying for the job. Difficulty and anxiety levels can double for classroom management when teaching in prison schools.

Working in prison education requires additional teacher training, awareness, and preparedness. Recognizing inmate students' mental, emotional, and social needs, backgrounds and conditions forces all factors, involved in correctional schooling, to work harder and better to offer a suitable educational program that will support prisoners' rehabilitation and reintegration. 


\section{LITERATURE REVIEW}

\section{Formal education within Kosovo Prisons}

Equal education, as offered to their peers in the common world, needs to be offered to inmate students, too. Professional schooling provided for convicts is going to support their rehabilitation while paying their debt to society. According to Boulianne \& Meunier (1986), "The ultimate goal of correctional systems is the successful reintegration of inmates into the mainstream of society." "Prisons will have some relationship to education outside, both in curriculum, methods of assessment for certification, overall aims and availability of resources" (UNESCO, 1995).

Meanwhile, only Lipjan and Dubrava correctional facilities offer formal education to inmates within Kosovo Correctional Service. Professional teachers from educational directorates from the above-mentioned cities are appointed. They follow the state curriculum as it is done by their counterparts in the free world. Gashi (2016) states that "formal education is obligatory within Lipjan correctional center that is divided into upper-secondary and technical-high schools offered to juvenile and female prisoners. While Dubrava correctional center offers only a technical-high school for its adult-male prisoners."

\section{Prison Classrooms Characteristics and Differences}

For centuries, everything that surrounds us, such as transportation, technology, lifestyle, etc. has changed, comparing our classrooms, too, results to be unchanged ever since. A 'box' (slightly upgraded by classroom technology, mostly in wealthy countries) still consists of only four walls, a door, windows, blackboard (whiteboard), chairs, and desks. No major differences can be seen for centuries within them. Most of them are still teacher-centered and force students to sit still and always obey their teachers. Unfortunately, the same concept is present within the education system in Kosovo Prisons, too.

Similar features of prison classrooms are present in almost all prisons around the world. The only differences are doors are made of iron and metal bar windows are covered by barbwires. Each prisoner student entering and leaving cell classrooms is searched by a CO. There is always a correctional officer guarding, outside of the cell classroom, in the corridor ready to jump in if needed. These differences disorganize the teachers' plans and slow down the teaching pace and process. "Perhaps the biggest challenge is that correctional facilities are, first and foremost, institutions of control and security, not classrooms or schools" (Brazzell, Crayton, Mukamal, 
Solomon, \& Lindahl, 2009). To a certain extent, a CO acts as a co-teacher that assists prison teachers from the prison school hall.

Prison administration and rules force teachers and inmates to feel entrapped and monitored in prison classrooms at all times as being part of the Big Brother reality show. Teachers need to have full autonomy of their classes to run them smoothly, productively professionally. According to Brazzell et al. (2009), "Programs should be provided in environments supportive of learning in which students feel physically safe and comfortable." Further on, Marzano, Marzano, and Pickering (as cited in Y1ldı, 2017) state that "Teachers need to be aware of student characteristics and needs for good classroom management." Wright, Horn, \& Sanders, (1997) (as cited in Stronge (2013) state that "the effectiveness of the teacher is the major determinant of student academic progress." Dual awareness needs to be present in lesson planning, activities prepared, time management and teaching materials selected. All of them need also to be adapted to cell classroom characteristics for a productive and effective class.

This professional awareness for teaching in prisons cannot be achieved only from knowledge gained and teaching skills developed from regular education faculties where teachers who teach in common schools are produced. According to the preliminary project report by LONCETT (2008) "no training customized to the particular needs of those teaching in prisons is currently available." Teachers, who plan to work within prison educational services, need professional training to prepare them professionally, mentally, and emotionally.

Apart from being familiar with safety and security conditions present within prison facilities, future teachers also need to develop skills and gain knowledge about teaching and managing classes full of inmate students. "It is self-evident that the students need their teachers in many types of learning environments" (Riley, 2009). Prison teaching characteristics are not similar to the ones the common schools in our society. Further, Frey et al. (1996) add that "Social justice is not done when 'we' give our time and energy to help 'them' escape from oppression; it is done when we realize that none of us is truly free while some of us are oppressed."

\section{Cell classrooms management}

According to Postholm (2013), "The aim of classroom management is twofold. The first is to establish a quiet and calm environment in the classroom so that the pupils can take part in meaningful learning in a subject. The second aim is that classroom management 
contributes to the pupils' social and moral development." Thus, classroom management issues were, are, and will always be present in classrooms in order both aims are achieved. There is no need to panic and give up on teaching within prison schooling or outside of it. Even the most experienced teachers face different issues with their classrooms.

Classroom management issues will always be in classrooms as long as educational systems will exist on the Earth. If a class is not properly prepared and planned and the needs, characteristics, and conditions of the students and educational facility are not taken into consideration, teachers will always face discipline issues in their classrooms followed by a lack of classroom productivity.

Weinstein, Woolfolk, Dittmeier \& Shanker (1994) explain that "some of the discipline problems that plague beginning teachers may be traced to the way they think about classroom management." Prison teachers need to take into consideration the emotional, mental, and social conditions of the inmate students and attend training to understand prison schooling before they enter the prison educational system. Related to teachers working within KCS, Gashi (2016) states that: "Teachers working within the prison walls are teachers who graduated from the common public education faculties in Kosovo." Because of that, lack of learning, productivity and classroom management issues are more likely to occur.

As pedagogues, we must strive to minimize classroom management issues by wellpreparing and respecting the dignity and circumstances of the inmate students. These will add value to teaching and learning processes within cell classrooms. According to Fry, Ketteridge and Marshall (2009) “Teachers and learners are both responsible for learning happening.” By ensuring better classroom management to prison-by-prison teachers and offering suitable educational opportunities to prisoners will help their rehabilitation and reintegration within prison premises. According to Doyle (1986), classroom management means a peaceful setting where students will learn and develop themselves socially, academically, and morally. Thus, the importance of classroom management increases especially when teaching within prison classrooms.

Further, due to safety controls and procedures, technical difficulties for prison teachers appear at the main entrance that follow them all along until they reach their cell classrooms. Mainly, teachers' hands are tight to bring supplementary materials and technology inside the prison classrooms. In order to have productive and engaging classes, fair and professional 
evaluation of their work, teachers need full autonomy in the prison educational system, especially with classroom management and evaluation of their work. According to Salah El (1980), the "teachers often display a slight fear of the prisoners, so they do not "press" the students much (...) nobody fails anything."

If already working prison teachers are not happy teaching in correctional facilities, there is a huge number of teachers, especially those from education faculties, who would like to contribute to prisoners' rehabilitation and reintegration through prison education. Also, they are ready to face all these challenges within correctional facilities whether as paid teachers or volunteers. Also, with rising numbers of people incarcerated in the USA, Zurro (2018) states that no matter the societal prejudice, many academics want to teach inside Prison premises and carry in them two characteristics ASAP to overcome classroom management obstacles as prison teachers: flexibility and resilience.

Prisoners can belong to different intellectual and safety categories within prison facilities. Not every prisoner is literate and knows the real value of education. Neither of them also has similar criminal backgrounds nor do all of them respect prison house rules. This diversity brings other issues into prison education. "Bringing inmate students of different security classifications together in the same classroom may be difficult" (Brazzell et al. 2009). Due to security issues, those prisoners who belong to a high-risk category are never brought together with prisoners from the general population in any circumstances, not even in the classrooms.

"Despite these challenges, education can flourish within the prison walls with the support of correctional administrators and a willingness on the part of correctional educators to teach within and around the constraints" (Brazzell et al. 2009). Challenges need to be recognized and solutions presented so the hours spent in prison classrooms, by prisoners, are productive. "It is rare for prisoners to be in classrooms for more than a few hours a day, and even though their time in them is productive and enjoyable, it is seldom that it can counteract the much stronger and deeply embedded learning that predates (and will postdate) prison" (UNESCO, 1995).

Brophy's finding (as cited in Weinstein et al. 1994) "contends that teachers who view classroom management as a process of guiding and structuring classroom events tend to be more effective than teachers who stress their disciplinary role." Mageehon's (2006) findings 
also showed that "woman prisoners expressed a desire to work with teachers who explained concepts and encouraged hands-on experimentation rather than simply assigned work." "In prisons, teachers do not humiliate or make their inmate-students feel unworthy, otherwise, they will rebel against everything that prison represents" (Salah El, 1980).

Gashi states (2016), that each prisoner is body searched before and at the end of the classes by a correctional officer at the entrance of the cell classrooms. They are inspected for any hidden illicit items that can injure teachers or peer-inmates during the lectures.

Prison teachers' cooperation with every stakeholder of prison education is of great pedagogic importance. Sharing ideas, strategies and challenges for a better prison classroom management, is necessary for better classroom management and a productive educational system to be offered for prisoners who want to return to society as free and educated citizens.

\section{CONCLUSION}

The conclusion is reached by the literature consulted and data collected from the formal education system within Kosovo Correctional Service by the author. It is understood that the characteristics, needs, and social status of prisoners need to be taken into consideration when

planning and managing prison classrooms populated by a special group of students. "These individuals often have difficulty succeeding in a regular classroom and may need specialized programming provided by expert instructors" (Brazzell et al. 2009). Rewarding the inmate students' achievements or punishing them for their failures or lack of discipline, trying to avoid any cell classroom management issues and ignoring the circumstances and characteristics of the prison educational system by teachers and other stakeholders, will reduce the productivity within prison classrooms.

Common teaching skills acquired within faculties of education are not enough to organize and deliver productive classes within correctional facilities. So, the prison teachers, who are teaching and planning to teach in a prison classroom, need to attend special training related to teaching in prison schooling. Prison teachers need to be familiar with prison students' characteristics attending schooling within prison walls. In cooperation with prison management, COs and teachers from different institutions in the common world, various classroom management strategies and effective teaching lessons can be brought to prison classrooms. 
Another characteristic of prison schooling is related to different categories of prisoners present within cell classrooms: detainees who are awaiting their trials and convicts serving their time. Sentenced prisoners are also divided into two main categories: common convicts and those presenting high risk. No matter their classification, individual teaching or special programs need to be offered to inmates from both groups. Special attention needs to be assigned to highrisk prisoners who are never to be put in the same classroom as prisoners who are accommodated within the common blocks or wings.

Certainly, designing a curriculum for a prison education system needs to involve all parties who require formal education to support prisoners' rehabilitation and reentry into society equip them with essential knowledge and must-have job skills. Because of that, teaching planning and learning materials, activities, games, and topics to be used within prison classrooms need to be chosen carefully and professionally. Because they are going to be used in cell classrooms populated by inmate students who once attended public schooling in the common world and were not successful; repeating the same mistakes by the prison education system, that possesses different characteristics, will add nothing to their rehabilitation and reintegration. 


\section{REFERENCES:}

Brazzell, D., Crayton, A., Mukamal, A.D., Solomon, L.A. \& Lindahl, N. (2009). From the Classroom to the Community. The Urbane Institute Justice Policy Center. John Jay College of Criminal Justice. https://eric.ed.gov/?id=ED508246

Boulianne, R. G., \& Meunier, C. (1986). PRISON EDUCATION: EFFECTS OF VOCATIONAL EDUCATION ON REHABILITATION. McGill Journal of Education / Revue Des Sciences De l'éducation De McGill, 21(003). Retrieved from https://mje.mcgill.ca/article/view/7679 Weinstein, S. C., Woolfolk, E. A., Dittmeier, L. \& Shanker, U. (1994) Protector or Prison Guard? Using Metaphors and Media to Explore Student Teachers' Thinking about Classroom Management, Action in Teacher Education, 16:1, 41-54, DOI:

10.1080/01626620.1994.10463187

Doyle, W. (1986). Classroom Organization and Management, in M. Wittrock (Ed.)

Handbook on Research on Teaching. 3, 392-431. London: Macmillan.

Frey, R. L., Pearce, B. W., Pollock, A. M., Artz, L., \& Murphy, O. B. (1996). Looking for Justice in All the Wrong Places: On a Communication Approach to Social Justice.

Communication Studies · March. DOI: 10.1080/10510979609368467

Fry, H., Ketteridge, S. \& Marshall, S. (2009). A Handbook for Teaching and Learning in Higher Education Enhancing Academic Practice. Taylor \& Francis.

Gashi, E. (2016). The Educational System in Kosovo Prisons. The State University of Tetovo.

LONCETT (2008). Initial teacher training project for teachers and instructors in prison and offender education. Preliminary Project Report. London Centre for Excellence in Teacher Training

Mageehon, A. (2006). What Makes a "Good" Teacher "Good:” Women in Transition From Prison to Community Reflect. Journal of Correctional Education, 57(2), 145-157.

http://www.jstor.org/stable/23282706

Postholm, B. M. (2013). Classroom Management: what does research tell us? European Educational Research Journal. 12(3). https://doi.org/10.2304/eerj.2013.12.3.389

Riley, P. (2009). An adult attachment perspective on the student-teacher relationship \& classroom management difficulties. Teaching and Teacher Education. 25(5), 626-635. DOI: $10.1016 /$ j.tate.2008.11.018 
Salah El, A. T. (1980). The Prison School. The Radical Teacher. Center for Critical Education, Inc. 16, 5-6. https://www.jstor.org/stable/20709252

Stronge, H. J. (2013). Effective Teachers = Student Achievement What the Research Says. Taylor \& Francis

United Nations (1995). Standard Minimum Rules for the Treatment of Prisoners. Retrieved on 18.12.2020 from

https://www.ohchr.org/EN/ProfessionalInterest/Pages/TreatmentOfPrisoners.aspx United Nations (1948). Universal Declaration of Human Rights. UN General Assembly UNESCO. (1995). Basic education of prisons. Institute for Education, Wienna, Austria. Y1ldız, G. N. (2017). Classroom Management and Student Achievement: A Study on Five Elementary Classrooms. AJESI - Anadolu Journal of Educational Sciences International. $7(1), 155-183$

Zurro, D. (2018). Learning from Prison. Retrieved on March 5 ${ }^{\text {th }}, 2021$ from https://www.insidehighered.com/views/2018/01/31/guidance-teaching-prisons-opinion 